\title{
One-Step Detection of Monilinia fructicola, M. fructigena, and M. laxa on Prunus and Malus by a Multiplex Real-Time PCR Assay
}

C. Guinet, C. Fourrier-Jeandel, I. Cerf-Wendling, and R. Ioos, Agence Nationale de Sécurité Sanitaire de l'Alimentation, de l'Environnement et du Travail (ANSES) Laboratoire de la Santé des Végétaux, Unité de Mycologie, Domaine de Pixérécourt, 54220 Malzéville, France

\begin{abstract}
Guinet, C., Fourrier-Jeandel, C., Cerf-Wendling, I., and Ioos, R. 2016. One-step detection of Monilinia fructicola, M. fructigena, and M. laxa on Prunus and Malus by a multiplex real-time PCR assay. Plant Dis. 100:2465-2474.

Brown rot is an economically important fungal disease affecting stone and pome fruit orchards, as well as harvested fruit during storage and on the market. Monilinia fructicola, M. laxa, and M. fructigena are the main causal agents of this disease and each have a different regulatory status depending on regional regulations. In this study, a new multiplex tool based on real-time polymerase chain reaction was developed to detect the three pathogenic fungi in a single reaction on fruit, twigs, and flowers of Prunus and Malus spp. Species-specific primer-hydrolysis probe combinations were designed to amplify a region located in a previously described

MO368 sequenced characterized amplified region marker, and used in a quadruplex format coupled with the $18 \mathrm{~S}$ Uni universal primer-probe test in order to check the quality of the DNA template. The assay was designed and optimized with the objective to provide high performance values. Experimental data supported its sensitivity, specificity, reproducibility, and robustness. In addition, a set of quality controls was implemented to minimize the risk of false-positive and false-negative results, thus making this new test fit for use in serial analyses and reliable in the framework of official controls.
\end{abstract}

Monilinia fructicola (G. Winter) Honey, M. fructigena Honey, and M. laxa (Aderh. \& Ruhland) Honey are the three most important fungi responsible for brown rot on Malus, Pyrus, and Prunus spp. (Batra 1991). This disease causes severe losses both before and after harvest in many stone and pome fruit orchards. Several fungicides are available to prevent or reduce the impact of the disease but resistance to demethylation inhibitor or methyl benzimidazole carbamate fungicides has been reported in $M$. fructicola, making chemical control more difficult (Chen et al. 2013). The three species have different regulatory statuses depending on the national plant protection organizations. M. fructicola is recorded as a quarantine fungus in Chile, Jordan, Israel, and Norway; M. fructigena in the United States, Canada, Australia, New Zealand, and Chile; and M. laxa in Jordan (European and Mediterranean Plant Protection Organization [EPPO] global database: https://gd.eppo.int/). Although, since 2014, M. fructicola is no longer listed as a quarantine pest in the European Union (EU; action directive 2014/78/UE), its distribution remains restricted to some regions of a limited number of EU countries (EPPO global database: https://gd.eppo.int/). In addition to M. fructicola, M. laxa, and $M$. fructigena, a fourth species (i.e., $M$. polystroma) has been reported on several occasions in Europe in the last 8 years on apricot, peach and apple (EPPO Reporting Service 2011; Hilber-Bodmer et al. 2012; Martini et al. 2014; Petróczy and Palkovics 2009; Poniatowska et al. 2013; Vasić et al. 2013). This species is likely of Japanese origin and is closely related to $M$. fructigena (Van Leeuwen et al. 2002).

Due to their quarantine status, reliable protocols are required to detect and identify the different species on traded plant material, especially on fruit that may carry these pathogens, with or without conspicuous symptoms. Distinguishing these four species remains difficult based on morphological traits (Muñoz et al. 2008; Sonoda et al. 1982; Van Leeuwen et al. 2002), especially because some of the cultural features may overlap between species (EPPO 2009a). Moreover, mixture of two species may occur on infected fruit (Ondejková et al. 2010), making it

Corresponding author: C. Guinet; E-mail: cecile.guinet@anses.fr

Accepted for publication 26 July 2016.

http://dx.doi.org/10.1094/PDIS-05-16-0655-RE

(C) 2016 The American Phytopathological Society difficult to isolate them in pure culture before study. However, several molecular-based assays targeting M. fructicola, M. laxa, and M. fructigena species have been developed and enable the limitations of identification based on culturing to be overcome. Most of the currently available molecular tests were initially designed to detect and distinguish M. fructicola from the other Monilinia spp. (Boehm et al. 2001; Förster and Adaskaveg 2000; Fulton and Brown 1997; Gell et al 2007; Luo et al. 2007; Ma et al. 2003; Van Brouwershaven et al. 2010), this taxon being the most destructive (Hrustic et al. 2012) and more often subjected to quarantine regulation. On the other hand, few tests enable the detection and identification of M. fructicola, M. laxa, and $M$. fructigena using conventional polymerase chain reaction (PCR), either by combining three monoplex assays (Hughes et al. 2000; Ioos and Frey 2000) or by a one-tube multiplex approach (Côté et al. 2004). Real-time PCR now offers improved specificity and a reduced turnaround time compared with conventional PCR, while being less prone to contamination issues due to the closed-tube system. Realtime PCR is also easily standardizable and transferable to laboratories that carry out serial analysis. Up to now, the available real-time tests only target either M. fructicola individually (Luo et al. 2007), or M. fructicola individually and all the other species grouped together (Van Brouwershaven et al. 2010). Our goal in this study was to take advantage of the multiplex format of real-time PCR using hydrolysis probes to develop a one-tube assay that enables the sensitive and simultaneous detection of $M$. fructicola, $M$. laxa, and $M$. fructigena. This new test targets interspecific polymorphisms in the MO368 sequenced characterized amplified region (SCAR) originally described by Côté et al. (2004), and can be used for the detection of the three pathogens directly in plant tissues. In addition, because reliability of the results are of paramount importance in the framework of phytosanitary regulations, performance data were generated and the assay was fully validated according to the EPPO guidelines (EPPO 2010). A set of quality controls were implemented and presented for the application of the test in serial analysis.

\section{Materials and Methods}

Fungal isolates. All the fungal isolates used in this study are listed in Table 1 and consist of a large set of Monilinia isolates from stems and fruit with different hosts and geographical origins, as well as other taxa commonly found on Monilinia host plants. The identity of all isolates was confirmed by coupling morphological identification and internal transcribed spacers (ITS) sequence analysis, using ITS1/ITS4 PCR primers (White et al. 1990). All the strains were 
grown on potato dextrose agar (PDA) for 7 days at $22 \pm 3{ }^{\circ} \mathrm{C}$ and a cycle of $12 \mathrm{~h} /$ day and $12 \mathrm{~h} /$ night. Pellets of aerial mycelium $(2 \mathrm{~mm}$ in diameter) were scratched from the cultures with a sterile scalpel blade and stored at $-20^{\circ} \mathrm{C}$ in a $2-\mathrm{ml}$ microtube until use.
Monilinia strains used for the inoculation experiments were cultured in the same conditions, and plugs of actively growing mycelium were punched out at the edge of the culture after 6 days of incubation.

Table 1. Fungal species used in this study to assess the specificity of the multiplex test

\begin{tabular}{|c|c|c|c|c|c|c|c|c|}
\hline \multirow[b]{2}{*}{ Species } & \multirow[b]{2}{*}{ Isolate } & \multirow[b]{2}{*}{ Host } & \multirow[b]{2}{*}{ Origin } & \multirow[b]{2}{*}{ Year ${ }^{\mathbf{b}}$} & \multicolumn{3}{|c|}{ Detection $(\text { mean } \mathrm{Ct} \text { value } \pm \mathrm{SD})^{\mathrm{a}}$} & \multirow[b]{2}{*}{$\mathbf{A c c}^{\mathrm{c}}$} \\
\hline & & & & & Mfcl & $M l x$ & Mfgn & \\
\hline M. fructicola & LSVM $177^{\mathrm{d}}$ & Prunus armeniaca & France & 2010 & $19.87 \pm 0.03$ & - & - & 343272 \\
\hline M. fructicola & LSVM 178 & P. avium & France & 2008 & $24.96 \pm 0.06$ & - & - & 343273 \\
\hline M. fructicola & LSVM 180 & P. persica & France & $\mathrm{ns}$ & $20.15 \pm 0.14$ & - & - & 343274 \\
\hline M. fructicola & CC935 & P. persica & United States & 1996 & $19.78 \pm 0.05$ & - & - & 343275 \\
\hline M. fructicola & DAR27029 & P. persica & Australia & 1976 & $20.62 \pm 0.07$ & - & - & 343276 \\
\hline M. fructicola & LSVM 183 & P. persica & France & $\mathrm{ns}$ & $19.53 \pm 0.05$ & - & - & 343277 \\
\hline M. fructicola & LSVM 185 & P. persica & France & $\mathrm{ns}$ & $21.02 \pm 0.21$ & - & - & 343278 \\
\hline M. fructicola & LSVM 1061 & P. persica & France & 2010 & $19.90 \pm 0.09$ & - & - & 343279 \\
\hline M. fructicola & LSVM 1062 & P. persica & France & 2010 & $23.69 \pm 0.26$ & - & - & 343280 \\
\hline M. fructicola & LSVM 1063 & P. persica & France & 2010 & $21.60 \pm 0.00$ & - & - & 343287 \\
\hline M. fructicola & LSVM 179 & P. persica & France & $\mathrm{ns}$ & $19.28 \pm 0.06$ & - & - & 343282 \\
\hline M. fructicola & LSVM 186 & P. persica & France & ns & $19.91 \pm 0.07$ & - & - & 343281 \\
\hline M. fructigena & LSVM 1043 & Malus pumila & France & 2013 & - & - & $20.76 \pm 0.27$ & 343270 \\
\hline M. fructigena & LSVM 1044 & Malus pumila & France & 1995 & - & - & $21.32 \pm 0.02$ & 343265 \\
\hline M. fructigena & LSVM 1046 & P. domestica & France & 1996 & - & - & $20.56 \pm 0.04$ & 343268 \\
\hline M. fructigena & LSVM 1045 & P. armeniaca & France & 1995 & - & - & $20.69 \pm 0.37$ & 343263 \\
\hline M. fructigena & $\operatorname{LSVM} 411^{\mathrm{d}}$ & P. armeniaca & France & 1995 & - & - & $19.61 \pm 0.09$ & 343271 \\
\hline M. fructigena & LSVM 453 & P. domestica & France & $\mathrm{ns}$ & - & - & $20.25 \pm 0.06$ & 343261 \\
\hline M. fructigena & LSVM 1047 & Prunus sp. & France & 1996 & - & - & $21.50 \pm 0.09$ & 343264 \\
\hline M. fructigena & LSVM 1048 & Pyrus sp. & France & 1996 & - & - & $20.25 \pm 0.45$ & 343267 \\
\hline M. fructigena & LSVM 1049 & Pyrus sp. & France & 1996 & - & - & $20.52 \pm 0.10$ & 343266 \\
\hline M. fructigena & LSVM 1052 & Malus sp. & France & 1996 & - & - & $20.58 \pm 0.03$ & 343262 \\
\hline M. fructigena & LSVM 1050 & Malus sp. & France & 1996 & - & - & $21.03 \pm 0.31$ & 343269 \\
\hline M. laxa & LSVM $412^{\mathrm{d}}$ & P. cerasus & France & 1996 & - & $17.61 \pm 0.01$ & - & 343260 \\
\hline M. laxa & LSVM 413 & Pyrus sp. & France & 1995 & - & $18.45 \pm 0.04$ & - & 343259 \\
\hline M. laxa & LSVM 414 & P. armeniaca & France & 2011 & - & $17.93 \pm 0.77$ & - & 343254 \\
\hline M. laxa & LSVM 796 & P. armeniaca & France & 2013 & - & $19.58 \pm 0.06$ & - & 343258 \\
\hline M. laxa & LSVM 797 & P. armeniaca & France & 2013 & - & $19.05 \pm 0.07$ & - & 343253 \\
\hline M. laxa & LSVM 798 & Malus domestica & France & 2013 & - & $20.23 \pm 0.05$ & - & 343255 \\
\hline M. laxa & LSVM 1055 & P. persica & France & 1996 & - & $19.46 \pm 0.02$ & - & 343257 \\
\hline M. laxa & LSVM 1057 & P. persica var. nucipersica & France & 1996 & - & $20.22 \pm 0.09$ & - & 343252 \\
\hline M. laxa & LSVM 1053 & P. armeniaca & France & 1995 & - & $20.39 \pm 0.22$ & - & 343250 \\
\hline M. laxa & LSVM 1056 & P. domestica & France & 1996 & - & $19.70 \pm 0.08$ & - & 343256 \\
\hline M. laxa & LSVM 1054 & P. cerasus & France & 1996 & - & $19.10 \pm 0.05$ & - & 343251 \\
\hline M. laxa & LSVM 1058 & P. persica & France & 2014 & - & $20.52 \pm 0.02$ & - & 343247 \\
\hline M. laxa & LSVM 1059 & P. armeniaca & France & 2014 & - & $19.43 \pm 0.04$ & - & 343248 \\
\hline M. laxa & LSVM 1060 & P. armeniaca & France & 2014 & - & $19.11 \pm 0.05$ & - & 343249 \\
\hline Monilia polystroma & CBS 102686 & Malus pumila & Japan & 2002 & - & - & - & AY456197 \\
\hline Monilia polystroma & CBS 102687 & Malus pumila & Japan & 2002 & - & - & - & 343283 \\
\hline Monilia polystroma & CBS 102688 & Malus pumila & Japan & 2002 & - & - & - & 343285 \\
\hline Monilia polystroma & CBS 122306 & Malus pumila & Japan & 2002 & - & - & - & 343284 \\
\hline Monilia polystroma & JAP2317 & Malus pumila & Japan & 1995 & - & - & - & 343286 \\
\hline Phlyctaenia vagabunda & LSVM 519 & M. pumila & France & 2012 & - & - & - & $\ldots$ \\
\hline Fusicladium asperatum & LSVM 596 & M. domestica & France & 2007 & - & - & - & $\ldots$ \\
\hline F. pyrorum & VP71 & Pyrus communis & Germany & 1995 & - & - & - & $\ldots$ \\
\hline F. pomi & LSVM 603 & M. floribonda & France & 1993 & - & - & - & $\ldots$ \\
\hline Alternaria sp. & LSVM 750 & P. communis & United States & 2013 & - & - & - & $\ldots$ \\
\hline Alternaria sp. & LSVM 753 & M. pumila & United States & 2013 & - & - & - & $\ldots$ \\
\hline Cryptosporiopsis & LSVM 1092 & P. communis & France & 2014 & - & - & - & $\ldots$ \\
\hline Alternaria sp. & LSVM 1093 & M. pumila & United States & 2014 & - & - & - & $\ldots$ \\
\hline Botrytis cinerea & LSVM 900 & Prunus domestica & United States & 2013 & - & - & - & $\ldots$ \\
\hline B. cinerea & LSVM 964 & Pinus sp. & France & 2014 & - & - & - & $\ldots$ \\
\hline Geotrichum sp. & $13-282$ & P. persica & France & 2013 & - & - & - & $\ldots$ \\
\hline Geotrichum sp. & $16-046 b$ & Malus sp. & France & 2016 & - & - & - & $\ldots$ \\
\hline Rhizopus oryzae & LSVM 4 & Helianthus annuus & France & 2009 & - & - & - & $\ldots$ \\
\hline
\end{tabular}

${ }^{a}$ Mean cycle threshold $(\mathrm{Ct})$ values \pm standard deviation $(\mathrm{SD} ; n=3$ ) yielded by the multiplex real time assay developed in this study of Monilinia fructicola (Mfcl), Monilinia laxa (Mlx), and Monilinia fructigena (Mfgn) with the MO368Mfcl, MO368Mlx, and MO368Mfgn primer-probe combination, respectively; - indicates $\mathrm{Ct}$ value $>40$ cycles, not detected.

${ }^{\mathrm{b}}$ Abbreviation: $\mathrm{ns}=$ not specified.

" GenBank accession numbers (all beginning with "KU") corresponding to the MO368 sequenced characterized amplified region marker.

$\mathrm{d}$ Isolate used for in vivo inoculation. 
DNA extraction. Fungal DNA was extracted by transferring the mycelium pellet into a $2-\mathrm{ml}$ microtube filled with $400 \mu \mathrm{l}$ of $1-\mathrm{mm}$ glass beads, $400 \mu \mathrm{l}$ of AP1 lysis buffer, and $4 \mu \mathrm{l}$ of RNase A provided with the DNeasy Plant minikit (Qiagen). The sample was homogenized for $30 \mathrm{~s}$ at $6.5 \mathrm{U}$ with the FastPrep 24 instrument (MP Biomedicals), then incubated for $15 \mathrm{~min}$ at $65^{\circ} \mathrm{C}$, and the DNA extraction was carried out following the manufacturer's instructions.

DNA was extracted from different types of diseased plant material. Fruit skin samples (fresh fruit or mummies) were excised using a 5$\mathrm{mm}$-diameter sterile cork borer. For naturally infected fruit or mummies, an entire 5-mm skin disc was used and transferred into a 2-ml Lysing Matrix A tube containing one 6-mm ceramic sphere and garnet matrix (MP Biomedicals); whereas, for artificially inoculated fruit, depending on the experiment, an entire skin disc, a half skin disc, or a quarter skin disc were used. Symptomatic flowers were used entirely and transferred individually into a 2-ml Lysing Matrix A tube. For necrotic twigs, fragments of $5 \mathrm{~mm}^{2}$ of symptomatic woody tissue were excised and cut in smaller parts with a sterile scalpel blade; then, all of the fragments were transferred into a 2-ml Lysing matrix A tube. Total DNA was extracted following the same protocol as described above for fungal DNA, except that the grinding step was extended to $2 \mathrm{~min}$.

Total DNA was quantified using the NanoDrop 2000 Spectrophotometer (Thermo Scientific).

Design of primers and hydrolysis probes. Several genomic DNA sequences were retrieved from GenBank and examined as candidates to design species-specific primer-probe combinations: ITS 1 and 2, cytochrome $b$ gene, and $\beta$-tubulin gene; however, these either offered very limited possibilities because of their poor level of interspecific variability between $M$. fructicola, $M$. laxa, and $M$. fructigena or showed unacceptable intraspecific variability (data not shown). However, the MO368 SCAR marker described by Côté et al. (2004) was retained based on the occurrence of clusters of species-specific polymorphic sites that were conserved within species. Partial sequences of the MO368 SCAR marker were generated by PCR for all of the Monilinia strains listed in Table 1. PCR amplification of the marker was carried out according to Côté et al. (2004), using MO368-5 as a forward primer for all species, and MO368-8R, MO368-10R, and Laxa-R2 as reverse primers for M. fructigena or M. polystroma, $M$. fructicola, and M. laxa, respectively. PCR amplicons were both strand sequenced by Beckman Coulters Genomics using the same primers as for amplification.

Partial MO368 sequences for several strains of M. fructicola $(n=12)$, M. fructigena $(n=11)$, M. laxa $(n=14)$, and M. polystroma $(n=5)$ were aligned using MUSCLE (Edgar 2004) implemented in the Geneious software (Biomatters) and manually scrutinized in order to identify suitable interspecific polymorphic regions with no intraspecific polymorphism.

Three sets of tentative primers and hydrolysis probe combinations specific to $M$. fructicola, $M$. laxa, and $M$. fructigena were designed using Primer 3 software (online version 0.4.0; http://bioinfo.ut.ee/ primer3-0.4.0/primer3/). The design of primers and probes was manually adjusted to amplify short fragments (approximately $150 \mathrm{pb}$ ). Melting temperature, potential secondary structures, and interhybridization within and between all primers and probes were evaluated in silico using PriDimerCheking online software (http://biocompute.
bmi.ac.cn/MPprimer/primer_dimer.html) and Geneious software. Then, the specificity of each candidate primer pair was assessed on a preliminary basis by a SYBR Green real-time PCR test with genomic DNA extract from all the isolates listed in Table 1. All primers and hydrolysis probes were custom synthesized by Eurogentec (Table 2).

Amplification by real-time PCR. The real-time PCR assays were performed on either a Rotor-Gene 6500 (Corbett Research) set with an autogain optimization for each channel performed before the first fluorescence acquisition or a LightCycler 480 (LC480; Roche) set with default parameters and with the color compensation algorithm activated as requested by the manufacturer for multiplex assays. All the PCR analyses were carried out using standard procedures to avoid DNA cross- and carry-over contaminations (Bustin et al. 2010). No-template controls were systematically included in duplicate to check for the absence of contamination. The cycle threshold $(\mathrm{Ct})$ value for each reaction was determined using the Rotor-Gene software (version 1.7.75), setting the threshold line manually at 0.02 for all the experiments, and the LightCycler480 software (version 1.5), performing an absolute quantification with the second derivative maximum method.

The test developed in this study consisted of a quadruplex real-time PCR amplification of species-specific regions within the MO368 SCAR marker and the $18 \mathrm{~S}$ Uni primer-probe combination that targets conserved regions of the $18 \mathrm{~S}$ ribosomal DNA (rDNA) of plants and fungi, and serves as a DNA extract quality control (Ioos et al. 2009). The realtime PCR amplifications were carried out in a total volume of $20 \mu \mathrm{lus}-$ ing the Mastermix No Rox kit (Eurogentec), consisting of $0.2 \mu \mathrm{M}$ each of the four forward and four reverse primers, $0.05 \mu \mathrm{M}$ each of the four probes, $1 \times$ reaction buffer, and $2 \mu l$ of template DNA (approximately $2 \mathrm{ng}$ ). PCR assays included an initial denaturation at $95^{\circ} \mathrm{C}$ for $10 \mathrm{~min}$ followed by 40 (45 for LC480) cycles of denaturation at $95^{\circ} \mathrm{C}$ for $15 \mathrm{~s}$ and annealing or elongation at $60^{\circ} \mathrm{C}$ for $60 \mathrm{~s}$.

Inclusivity and specificity. The specificity of the real-time PCR assay (i.e., the ability of the test not to cross-react with DNA of nontarget species in either monoplex or quadruplex reactions) was assessed with DNA extracts prepared from a collection of 42 strains representing the four species of Monilinia, collected from stem and fruit, and 17 strains of different fungi commonly found on fruit trees (Table 1). All DNA extracts were normalized to a concentration of $1 \mathrm{ng} \mu \mathrm{l}^{-1}$ prior to testing. The inclusivity of the test was checked with DNA from $12 \mathrm{M}$. fructicola isolates, $11 \mathrm{M}$. fructigena isolates, and 14 M. laxa isolates, collected from different hosts, organs, and geographical origins over several years.

Furthermore, 47 naturally infected fruit, mummies, flowers, and twig samples were collected and tested for the presence of $M$. fructicola, M. laxa, or M. fructigena using this new quadruplex assay (Table 3). Some of the PCR amplicons generated with DNA from naturally infected plant material were sequenced by Beckman Coulters Genomics using the same primers as for amplification, and homology searches on GenBank using BLAST algorithm were performed to confirm the specificity of the assays.

Implementation of qPCR quality controls. Limit of detection (LOD) positive controls and a specificity control were developed as follows. The PCR products amplified using the primer pairs

Table 2. Primers and probes developed and used in this study

\begin{tabular}{|c|c|c|c|c|}
\hline Target $^{\mathbf{a}}$ & Name & Sequence $\left(5^{\prime}-3^{\prime}\right)^{\mathbf{b}}$ & Size (bp) & $\operatorname{Tm}\left({ }^{\circ} \mathbf{C}\right)$ \\
\hline \multirow[t]{3}{*}{ M. fructicola } & Mfcl368-F & ACTAAACGACGCGGTAATGG & 20 & 60.02 \\
\hline & Mfcl368-R & CTTTTAACTTCTTAGCCGCTCCA & 23 & 61.16 \\
\hline & Mfcl368-P & FAM-CACGAATGTCGTGAAAGGATAATGGA-BHQ1 & 26 & 66.99 \\
\hline \multirow[t]{3}{*}{ M. fructigena } & Mfgn368-F & AGCACAGCGAGTACAATAAGC & 21 & 57.37 \\
\hline & Mfgn368-R & TACCCAGACACCACCTCCTC & 20 & 59.96 \\
\hline & Mfgn368-P & Cy5-TGCTCCGTAGGCAATCGGTAAAGA-BHQ2 & 24 & 67.80 \\
\hline \multirow[t]{3}{*}{ M. laxa } & Mlx368-F & CCAAGGGCTCCGTAGGTAA & 19 & 60.07 \\
\hline & Mlx368-R & TCCACACCGTCGAACAATAA & 20 & 59.96 \\
\hline & Mlx368-P & ROX-CAGATCGTGAAGGGCGTGAGGT-BHQ2 & 22 & 68.00 \\
\hline
\end{tabular}

\footnotetext{
a Target amplicon sizes were 151, 151, and 159 for Monilinia fructicola, M. fructigena, and M. laxa, respectively.
}

${ }^{\mathrm{b}}$ Data in bold corresponds to the dye and quencher of the probes. 
Mfgn368-F/R, Mlx368-F/R, MO368-5/10R, and MO368-5/8R from M. fructigena (LSVM 411), M. laxa (LSVM 412), M. fructicola (LSVM 177), and $M$. polystroma (CBS 102686) genomic DNA, respectively, were cloned using the $\mathrm{pCR} 4-\mathrm{TOPO}$ vector and the chemically competent TOP10 cells (Invitrogen), according to the manufacturer's instructions. After an overnight incubation of the transformed bacterial cells, plasmids were purified using a NucleoSpin Plasmid kit (MachereyNagel). The M. fructicola, M. laxa, and M. fructigena purified plasmid

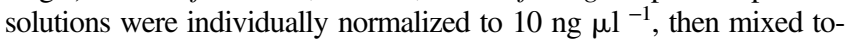
gether and 10-fold serial diluted in $1 \times$ Tris-EDTA buffer in order to determine the minimal quantity of target DNA that could be reliably detected and would correspond to the LOD concentration. The $M$. polystroma target plasmid solution was set at 22,300 plasmidic copies (pc) $\mu \mathrm{l}^{-1}$ and used throughout the experiments as a specificity control in order to constantly verify the specificity of the quadruplex reactions, by yielding a negative result for all primer-probe combinations.

In addition, in order to prevent the occurrence of false-negative results during routine analyses, the quality of each template DNA was individually assessed by the $18 \mathrm{~S}$ Uni-F/-R/-P included in each multiplex real-time assay (Ioos et al. 2009). A cut-off value was preliminarily determined for the $18 \mathrm{~S}$ Uni test $\left(\mathrm{Ct}_{18 \mathrm{~S}}\right)$, beyond which a DNA extract was deemed unsuitable for PCR analysis (presence of inhibiting compounds, poor DNA yield, and so on). $\mathrm{Ct}_{18 \mathrm{~s}}$ was initially determined by computing the mean and standard deviation (SD) of the $18 \mathrm{~S}$ Uni Ct values obtained with DNA from a series of 30 healthy skin samples from six varieties of apple ('Ariane', 'Altesse', 'Golden',

Table 3. Naturally infected samples tested for the presence of Monilinia fructicola $(M f c l), M$. laxa $(M l x)$, and M. fructigena (Mfgn) by the multiplex real-time polymerase chain reaction (PCR) developed in this study

\begin{tabular}{|c|c|c|c|c|c|c|}
\hline \multirow[b]{2}{*}{ Host } & \multirow[b]{2}{*}{ Organ } & \multirow[b]{2}{*}{ Origin (France) } & \multicolumn{4}{|c|}{ Detection $(\text { mean } \mathrm{Ct} \text { value } \pm \mathrm{SD})^{\mathrm{a}}$} \\
\hline & & & $M f c l$ & $M l x$ & Mfgn & 18S Uni \\
\hline Prunus domestica & Mummified fruit & Meurthe-et-Moselle & $>40$ & $20.41 \pm 0.42^{b}$ & $>40$ & $20.38 \pm 0.43$ \\
\hline$P$. persica & Infected fruit & Haute-Corse & $>40$ & $22.54 \pm 0.51^{\mathrm{b}}$ & $>40$ & $15.04 \pm 0.23$ \\
\hline P. persica & Infected fruit & Haute-Corse & $>40$ & $>40$ & $18.35 \pm 0.13^{\mathrm{b}}$ & $14.05 \pm 0.07$ \\
\hline Malus domestica & Necrosis on twig & Aveyron & $>40$ & $20.17 \pm 0.04^{\mathrm{b}, \mathrm{c}}$ & $>40$ & $13.88 \pm 0.13^{\mathrm{c}}$ \\
\hline M. domestica & Infected fruit & Meurthe-et-Moselle & $>40$ & $>40$ & $17.35 \pm 0.21^{\mathrm{b}}$ & $14.75 \pm 0.07$ \\
\hline M. domestica & Infected fruit & Meurthe-et-Moselle & $>40$ & $23.74 \pm 0.11^{\mathrm{b}, \mathrm{c}}$ & $29.59 \pm 0.46^{\mathrm{b}, \mathrm{c}}$ & $17.63 \pm 0.08^{c}$ \\
\hline M. domestica & Infected fruit & Meurthe-et-Moselle & $>40$ & $32.91 \pm 0.33^{\mathrm{b}, \mathrm{c}}$ & $>40$ & $21.52 \pm 0.06^{\mathrm{c}}$ \\
\hline P. armeniaca & Necrosis on twig & Haute-Corse & $>40$ & $21.38 \pm 0.21^{\mathrm{b}}$ & $>40$ & $11.45 \pm 0.24$ \\
\hline P. armeniaca & Infected flower & Haute-Corse & $>40$ & $20.68 \pm 0.25^{\mathrm{d}}$ & $>40$ & $13.43 \pm 0.01^{\mathrm{d}}$ \\
\hline P. armeniaca & Mummified fruit & Haute-Corse & $>40$ & $24.91 \pm 0.22^{\mathrm{b}}$ & $>40$ & $13.88 \pm 0.02$ \\
\hline P. cerasus & Necrosis on twig & Meurthe-et-Moselle & $>40$ & $33.13 \pm 0.47^{b}$ & $>40$ & $13.04 \pm 0.03$ \\
\hline M. domestica & Mummified fruit & Vienne & $>40$ & $>40$ & $21.98 \pm 0.06^{\mathrm{c}}$ & $19.34 \pm 0.05^{\mathrm{c}}$ \\
\hline P. cerasus & Mummified fruit & Meurthe et Moselle & $>40$ & $19.43 \pm 0.24^{\mathrm{b}}$ & $>40$ & $15.35 \pm 0.02$ \\
\hline P. domestica subsp. insititia & Necrosis on twig & Haute-Corse & $>40$ & $33.90 \pm 0.36^{b, c}$ & $>40$ & $11.80 \pm 0.06^{\mathrm{c}}$ \\
\hline P. domestica subsp. insititia & Mummified fruit & Haute-Corse & $>40$ & $16.42 \pm 0.14^{\mathrm{b}}$ & $>40$ & $18.85 \pm 0.16$ \\
\hline$P$. persica & Necrosis on twig & Haute-Corse & $>40$ & $25.82 \pm 0.15^{\mathrm{b}, \mathrm{c}}$ & $>40$ & $12.45 \pm 0.03^{\mathrm{c}}$ \\
\hline P. persica & Infected flower & Haute-Corse & $>40$ & $18.79 \pm 0.10^{\mathrm{b}, \mathrm{c}}$ & $>40$ & $10.97 \pm 0.06^{\mathrm{c}}$ \\
\hline P. persica & Mummified fruit & Haute-Corse & $>40$ & $16.59 \pm 0.20^{\mathrm{b}}$ & $>40$ & $18.08 \pm 0.28$ \\
\hline P. persica & Necrosis on twig & Gard & $15.65 \pm 0.13^{b}$ & $>40$ & $>40$ & $9.65 \pm 0.23$ \\
\hline P. persica & Necrosis on twig & Gard & $16.01 \pm 0.24^{b}$ & $>40$ & $>40$ & $10.78 \pm 0.11$ \\
\hline P. persica & Necrosis on twig & Gard & $14.79 \pm 0.04^{b}$ & $>40$ & $>40$ & $10.61 \pm 0.02$ \\
\hline P. persica & Necrosis on twig & Gard & $14.76 \pm 0.11^{\mathrm{b}}$ & $>40$ & $>40$ & $10.22 \pm 0.06$ \\
\hline P. persica & Necrosis on twig & Gard & $14.98 \pm 0.25$ & $>40$ & $>40$ & $12.49 \pm 0.23$ \\
\hline P. armeniaca & Infected flower & Ardèche & $23.45 \pm 0.06^{\mathrm{c}}$ & $>40$ & $>40$ & $10.87 \pm 0.04^{c}$ \\
\hline P. armeniaca & Infected flower & Ardèche & $25.07 \pm 0.13^{\mathrm{d}}$ & $>40$ & $>40$ & $11.62 \pm 0.19^{d}$ \\
\hline P. armeniaca & Necrosis on twig & Drôme & $>40$ & $20.30 \pm 0.09^{c}$ & $>40$ & $12.08 \pm 0.03^{\mathrm{c}}$ \\
\hline P. armeniaca & Infected flower & Drôme & $>40$ & $31.70 \pm 0.53^{\mathrm{d}}$ & $>40$ & $8.98 \pm 0.05^{\mathrm{d}}$ \\
\hline P. armeniaca & Necrosis on twig & Drôme & $>40$ & $21.72 \pm 0.35$ & $>40$ & $12.34 \pm 0.12$ \\
\hline P. armeniaca & Infected flower & Drôme & $>40$ & $23.70 \pm 0.13^{\mathrm{d}}$ & $>40$ & $12.75 \pm 0.09^{\mathrm{d}}$ \\
\hline P. armeniaca & Necrosis on twig & Drôme & $>40$ & $25.40 \pm 0.10^{\mathrm{d}}$ & $>40$ & $16.09 \pm 0.05^{\mathrm{d}}$ \\
\hline P. armeniaca & Infected flower & Drôme & $>40$ & $26.20 \pm 0.50^{\mathrm{d}}$ & $>40$ & $13.54 \pm 0.38^{d}$ \\
\hline P. armeniaca & Necrosis on twig & Drôme & $>40$ & $21.78 \pm 0.26$ & $>40$ & $11.21 \pm 0.11$ \\
\hline P. armeniaca & Infected flower & Drôme & $>40$ & $21.9 \pm 0.15^{\mathrm{d}}$ & $>40$ & $12.62 \pm 0.33^{\mathrm{d}}$ \\
\hline P. armeniaca & Necrosis on twig & Drôme & $>40$ & $23.50 \pm 0.15^{\mathrm{c}}$ & $>40$ & $11.73 \pm 0.03^{c}$ \\
\hline P. armeniaca & Infected flower & Drôme & $>40$ & $22.50 \pm 014^{\mathrm{d}}$ & $>40$ & $12.95 \pm 0.05^{\mathrm{d}}$ \\
\hline P. armeniaca & Necrosis on twig & Drôme & $>40$ & $21.92 \pm 0.17$ & $>40$ & $13.65 \pm 0.22$ \\
\hline P. armeniaca & Infected flower & Drôme & $>40$ & $26.70 \pm 1.51^{\mathrm{d}}$ & $>40$ & $15.34 \pm 0.30^{\mathrm{d}}$ \\
\hline P. armeniaca & Necrosis on twig & Drôme & $>40$ & $21.80 \pm 0.02^{\mathrm{c}}$ & $>40$ & $12.68 \pm 0.04^{\mathrm{c}}$ \\
\hline P. armeniaca & Infected flower & Drôme & $>40$ & $28.70 \pm 0.20^{\mathrm{d}}$ & $>40$ & $12.76 \pm 0.08^{\mathrm{d}}$ \\
\hline P. armeniaca & Mummified fruit & Drôme & $22.86 \pm 0.30$ & $18.63 \pm 0.32$ & $>40$ & $19.51 \pm 0.37$ \\
\hline P. armeniaca & Mummified fruit & Drôme & $>40$ & $20.4 \pm 0.14^{c}$ & $>40$ & $17.32 \pm 0.14^{\mathrm{c}}$ \\
\hline P. armeniaca & Mummified fruit & Drôme & $>40$ & $18.7 \pm 0.12^{\mathrm{c}}$ & $>40$ & $18.19 \pm 0.14^{\mathrm{c}}$ \\
\hline P. armeniaca & Mummified fruit & Drôme & $>40$ & $19.9 \pm 0.09^{d}$ & $>40$ & $19.51 \pm 0.20^{\mathrm{d}}$ \\
\hline P. armeniaca & Mummified fruit & Drôme & $>40$ & $16.89 \pm 0.60$ & $>40$ & $18.14 \pm 0.76$ \\
\hline P. armeniaca & Mummified fruit & Drôme & $>40$ & $24.22 \pm 0.90$ & $>40$ & $23.77 \pm 0.50$ \\
\hline P. armeniaca & Mummified fruit & Drôme & $>40$ & $17.07 \pm 0.32$ & $>40$ & $16.62 \pm 0.15$ \\
\hline P. armeniaca & Infected flower & Drôme & $>40$ & $22.50 \pm 0.14^{\mathrm{d}}$ & $>40$ & $12.95 \pm 0.05^{\mathrm{d}}$ \\
\hline
\end{tabular}

${ }^{a}$ Cycle threshold $(\mathrm{Ct}) \pm$ standard deviation $(\mathrm{SD} ; n=3) ;>40$ indicates not detected.

b $\mathrm{PCR}$ product was sequenced.

${ }^{\mathrm{c}}$ DNA extract was 10 -fold diluted before analysis because no $\mathrm{Ct}$ value was obtained with any of the four assays for the nondiluted DNA extract.

${ }^{\mathrm{d}}$ DNA extract was 100-fold diluted before analysis because no $\mathrm{Ct}$ value was obtained with any of the four assays for the 10-fold diluted DNA extract. 
'Royal Gala', 'Pirouette', and 'Boskoop'). Each sample consisted of two 5 -mm skin discs removed from apple fruit with a cork-borer. The normal distribution of the $18 \mathrm{~S}$ Uni Ct values was confirmed by a ShapiroWilk's normality test using the Rcmdr package (Fox 2005) with Rproject version 3.1.3 (R Core Team 2015), which showed that $95 \%$ of the $18 \mathrm{~S}$ Uni Ct value would be expected to be included within the mean \pm 2 SD interval.

Performance criteria of the quadruplex assay. In order to verify the fitness of the quadruplex assay for routine analysis, the major performance criteria were assessed.

Sensitivity was assessed first with plasmidic DNA controls diluted in 1× Tris-EDTA buffer or in a background of fruit DNA. The fruit DNA extract was obtained from an equal mixture prepared with skin of apple, cherry, apricot, pear, and plum and adjusted to $1 \mathrm{ng} \mathrm{\mu l}^{-1}$. Furthermore, the sensitivity of this new assay was also assessed according to Riccioni and Valente (2015) with spiked samples. In brief, fruit skin DNA from six varieties of apple (Ariane, Altesse, Golden, Royal Gala, Pirouette, and Boskoop) set at $0.15{\mathrm{ng} \mu \mathrm{l}^{-1}}^{-1}$ were spiked with DNA from M. fructicola (LSVM 177), M. laxa (LSVM 412), or $M$. fructigena strains (LSVM 411) with four levels of DNA concentrations $\left(0.125,0.25,25\right.$, and $\left.250 \mathrm{pg}^{-1}\right)$ and tested in triplicate.

Replicability was evaluated with 10 replicates of the target plasmidic DNA from each species tested in the same run, while reproducibility was evaluated with one replicate of the target plasmidic DNA for each species in 10 different runs over a 4-week period, with two different operators and two different Rotor-Gene thermal cyclers. Replicability and reproducibility were assessed with plasmidic DNA controls set at $10 \times \mathrm{LOD}, 100 \times \mathrm{LOD}$, and $1,000 \times \mathrm{LOD}$ concentrations diluted in a background of $1 \mathrm{ng} \mu \mathrm{l}^{-1}$ fruit DNA. For each condition, intra- and interassay coefficients of variation $(\mathrm{CV})$ were calculated.

The robustness of the quadruplex real-time PCR assay was evaluated by deliberately modifying several method parameters, in order to simulate minor experimental drifts or errors that may occur during normal use. Sensitivity and specificity of the tests were challenged with a $\pm 10 \%$ variation of the individual reaction volume or of the DNA template volume, with slight variations of the hybridization temperature $\left( \pm 2^{\circ} \mathrm{C}\right)$ and with the use of two different thermal cyclers. The parameters were modified and multiplex assays were run with 10 replicates of $M$. fructicola, $M$. laxa, and M. fructigena plasmidic DNA controls set at LOD and 100× LOD concentrations, and with genomic DNA from $M$. polystroma (CBS 102686), M. fructicola (LSVM 177), M. laxa (LSVM 412), and M. fructigena (LSVM 411) set at $1 \mathrm{ng} \mu \mathrm{l}^{-1}$.
In order to check that the multiplex assay was transferable to different real-time PCR equipment, additional analyses were performed using the LC480 thermal cycler (PCR block format), with the same time and temperature settings for the PCR cycles. For this, the multiplex real-time PCR was run with 10 replicates of plasmidic DNA controls set at LOD and 100× LOD concentrations; 10 replicates of $M$. polystroma plasmidic DNA specificity control; and 3 replicates of genomic DNA at $1 \mathrm{ng} \mu \mathrm{l}^{-1}$ from $M$. fructicola (LSVM 177), M. fructigena (LSVM 411), M. laxa (LSVM 412), M. polystroma (CBS 102686), Fusicladium asperatum (LSVM 596), F. pyrorum (LSVM 601), F. pomi (LSVM 603), an Alternaria sp. (LSVM 750 and LSVM 753), Botrytis cinerea (LSVM 900 and LSVM 964), a Geotrichum sp. (12-282 and 16-041b), and Rhizopus oryzae (LSVM 4).

Statistical analyses were performed using the Rcmdr package under R-project version 3.1.3 by one-way analysis of variance. Differences between mean values for each variable were assessed using Tukey's honestly significant difference test. $\mathrm{Ct}$ value for a negative sample was set to 40 .

Tests of in vivo inoculations. Three sets of organically grown 'Golden Delicious' apple and yellow peach (unknown cultivar) were artificially inoculated. The fruit were surface sterilized with $70 \%$ ethanol and cut-injured with a 5-mm-diameter cork-borer. All inoculations were carried out by inserting a 5-mm-diameter agar plug taken at the edge of a 6-day-old fungal culture into the hole in the fruit, and the fruit were incubated at $22^{\circ} \mathrm{C}$ for 6 and 7 days for apple and peach, respectively. Strains LSVM 177 (M. fructicola), LSVM 412 (M. laxa), and LSVM 411 (M. fructigena) were used throughout the experiments.

A first set (set A) corresponded to fruit inoculated with a single Monilinia sp. (M. laxa, M. fructicola, or M. fructigena). For each Monilinia sp., one peach and one apple fruit were each inoculated at two diametrically opposed spots. After incubation, for each fruit, five replicates of two 5-mm skin discs were sampled using a sterile cork-borer at a distance of $2 \mathrm{~cm}$ from each of the two spots of inoculation, and transferred into five sterile microtubes until DNA extraction.

A second set (set B) corresponded to fruit simultaneously inoculated with two Monilinia spp. (M. fructicola and M. laxa, M. fructicola and M. fructigena, or M. laxa and M. fructigena). For each combination of coinoculation, one peach and one apple fruit were inoculated at two diametrically opposed spots with either species. After incubation, for each fruit, five replicates of two 5-mm skin discs were sampled using a sterile cork-borer at the intersection of the necrotic areas generated by the two species, and transferred into five sterile microtubes until DNA extraction.

Table 4. Sensitivity of the multiplex assay assessed with artificially inoculated fruit samples in three experimental sets

\begin{tabular}{|c|c|c|c|c|c|c|c|c|}
\hline \multirow[b]{3}{*}{ Sets } & \multicolumn{8}{|c|}{ Mean Ct values $( \pm S D)^{a}$} \\
\hline & \multicolumn{2}{|c|}{$M f c l$} & \multicolumn{2}{|c|}{$M l x$} & \multicolumn{2}{|c|}{ Mfgn } & \multicolumn{2}{|c|}{ 18S Uni } \\
\hline & Apple & Peach & Apple & Peach & Apple & Peach & Apple & Peach \\
\hline \multicolumn{9}{|l|}{ A } \\
\hline$M f c l$ & $22.6 \pm 0.6$ & $16.9 \pm 0.2$ & $>40$ & $>40$ & $>40$ & $>40$ & $17.9 \pm 0.5$ & $8.6 \pm 0.4$ \\
\hline$M l x$ & $>40$ & $>40$ & $20.6 \pm 0.5$ & $18.2 \pm 0.6$ & $>40$ & $>40$ & $15.4 \pm 0.3$ & $11.6 \pm 0.7$ \\
\hline Mfgn & $>40$ & $>40$ & $>40$ & $>40$ & $20.9 \pm 1.2$ & $16.1 \pm 0.7$ & $15.5 \pm 1.0$ & $11.5 \pm 1.0$ \\
\hline Control fruit & $>40$ & $>40$ & $>40$ & $>40$ & $>40$ & $>40$ & $12.2 \pm 0.7$ & $9.7 \pm 0.8$ \\
\hline \multicolumn{9}{|l|}{$\mathrm{B}$} \\
\hline$M f c l / M l x$ & $19.8 \pm 0.4$ & $19.0 \pm 1.7$ & $21.5 \pm 0.8$ & $23.9 \pm 3.4$ & $>40$ & $>40$ & $13.9 \pm 0.4$ & $8.5 \pm 0.4$ \\
\hline$M f c l / M f g n$ & $20.0 \pm 0.5$ & $17.7 \pm 1.6$ & $>40$ & $>40$ & $19.1 \pm 1.0$ & $23.5 \pm 3.1$ & $13.8 \pm 0.3$ & $6.4 \pm 0.4$ \\
\hline$M l x / M f g n$ & $>40$ & $>40$ & $21.6 \pm 0.6$ & $19.7 \pm 2.7$ & $20.8 \pm 1.0$ & $17.5 \pm 0.9$ & $14.2 \pm 0.4$ & $7.1 \pm 0.2$ \\
\hline \multicolumn{9}{|l|}{$\mathrm{C}$} \\
\hline $1 / 2 M f c l, 1 M l x, 1 M f g n$ & $22.4 \pm 0.4$ & $18.2 \pm 0.9$ & $22.9 \pm 1.9$ & $16.1 \pm 1.7$ & $21.3 \pm 1.0$ & $15.6 \pm 0.9$ & $14.7 \pm 0.4$ & $11.4 \pm 0.9$ \\
\hline $1 / 2 M l x, 1 M f c l, 1 M f g n$ & $20.6 \pm 0.4$ & $17.4 \pm 0.6$ & $26.9 \pm 6.8^{b}$ & $32.2 \pm 6.9^{\mathrm{b}}$ & $21.3 \pm 1.9$ & $15.7 \pm 0.4$ & $14.8 \pm 0.5$ & $10.7 \pm 0.6$ \\
\hline $1 / 2 M f g n, 1 M f c l, 1 M l x$ & $20.9 \pm 0.7$ & $17.7 \pm 0.5$ & $23.0 \pm 1.1$ & $18.1 \pm 0.8$ & $22.4 \pm 0.6$ & $17.8 \pm 0.4$ & $15.0 \pm 0.3$ & $10.7 \pm 0.6$ \\
\hline $1 / 4 M f c l, 1 M l x, 1 M f g n$ & $24.4 \pm 0.5$ & $20.2 \pm 0.2$ & $23.0 \pm 1.9$ & $16.9 \pm 2.8$ & $21.8 \pm 1.1$ & $16.7 \pm 0.7$ & $15.5 \pm 0.3$ & $12.3 \pm 0.8$ \\
\hline $1 / 4 M l x, 1 M f c l, 1 M f g n$ & $21.4 \pm 0.7$ & $16.8 \pm 0.8$ & $31.0 \pm 5.6^{\mathrm{b}}$ & $18.3 \pm 3.5$ & $22.4 \pm 0.9$ & $15.4 \pm 0.4$ & $15.7 \pm 0.4$ & $10.1 \pm 0.6$ \\
\hline 1/4 Mfgn, $1 M f c l, 1 M l x$ & $21.2 \pm 0.8$ & $17.2 \pm 0.7$ & $22.2 \pm 1.9$ & $20.8 \pm 1$ & $24.7 \pm 0.8$ & $18.8 \pm 0.4$ & $15.3 \pm 0.5$ & $10.2 \pm 0.5$ \\
\hline
\end{tabular}

${ }^{a}$ Cycle threshold $(\mathrm{Ct}) \pm$ standard deviation (SD; $\left.n=15\right)$ for Monilinia fructicola $(M f c l)$, M. laxa (Mlx), and M. fructigena (Mfgn); $>40$ indicates not detected.

${ }^{b}$ One replicate out of five yielded a $\mathrm{Ct}$ value $>40$. 
A third set (set C) corresponded to fruit simultaneously inoculated with the three Monilinia spp. (M. fructicola, M. laxa, and M. fructigena). Five apple and five peach fruit were each inoculated with each of the three species at three spots with an angle of $120^{\circ}$ between each spot. After incubation, for each fruit, five 5-mm skin discs were removed at a distance of $2 \mathrm{~cm}$ from the inoculation point and in skin areas where no sporulating cushions were visible. Depending on the following experiments, the discs were either kept whole or cut in halves or quarters, and the contaminated skins were mixed in five replicates according to the different ratios described in Table 4.

For the three sets, a control peach and a control apple fruit were inoculated with sterile PDA and incubated following the same conditions. After incubation, for each control fruit, five replicates of two 5-mm skin discs were sampled using a sterile cork-borer at a
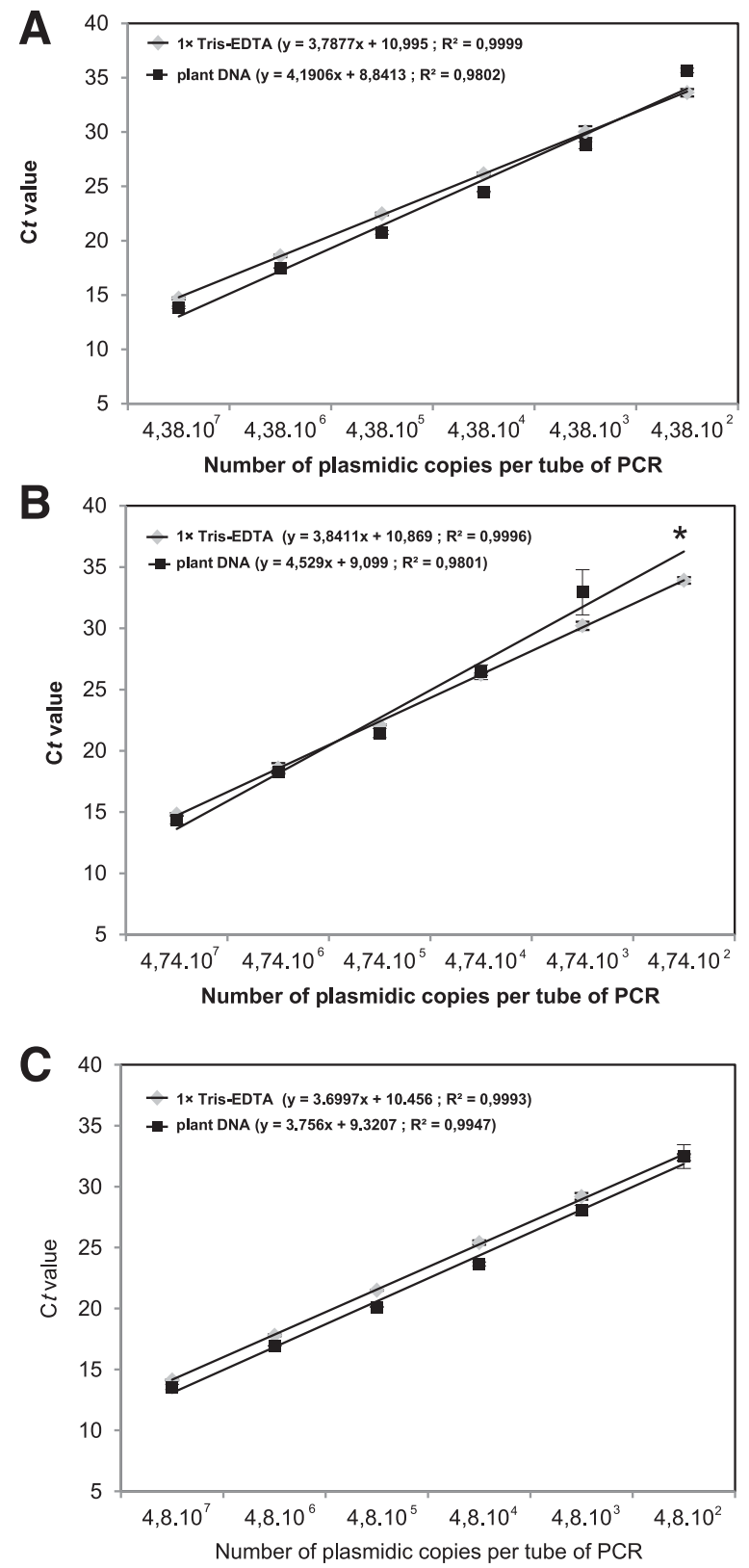

Fig. 1. Standard curve assessed with a 10-fold serial dilution of the A, Monilinia fructicola; B, M. laxa; or C, M. fructigena plasmidic DNA-positive controls diluted in 1x Tris-EDTA buffer (gray diamond) or in a background of plant DNA (black square). Values are the mean cycle threshold $(\mathrm{Ct})$ values \pm standard deviation $(n=10) ;{ }^{*}$ indicates no $\mathrm{Ct}$ value was obtained. PCR $=$ polymerase chain reaction. distance of $2 \mathrm{~cm}$ from each of the two spots of inoculation, and transferred into five sterile microtubes until DNA extraction.

\section{Results}

Inclusivity and specificity. When tested in multiplex PCR, all the DNA extracts from each target species yielded positive results with the corresponding species-specific primer-probe combination, regardless of host, geographical origin, and year of collection. No cross reaction with nontarget species was observed (Table 1). Identical results were obtained in monoplex real-time assays using each primer-probe combination individually (data not shown). In addition, the quadruplex assay did not cross-react with DNA from $M$. polystroma or any other Ascomycotina species isolated from stone and pome fruit and stems from various orchards, thus supporting its analytical specificity.

Positive results for the $M$. fructicola, $M$. laxa, or M. fructigena assays were obtained with naturally infected plant samples, and 20 randomly selected amplicons generated were sequenced (Table 3). The sequence of each amplicon was $100 \%$ identical to the expected target sequence, thus confirming the specificity of the test with naturally contaminated plant material. For more than half of the samples, the DNA extract had to be diluted 10-fold or 100-fold due to inhibitory compounds coextracted with nucleic acid, according to the $\mathrm{Ct}$ value obtained with the 18S Uni assay (Table 3).

Sensitivity. When using positive controls diluted in $1 \times$ TrisEDTA, the quadruplex real-time PCR test yielded repeatable positive results with as low as 438, 474, and 480 plasmid copies of the target per PCR tube for $M$. fructicola, M. laxa, and M. fructigena, respectively. These values were defined as the LOD concentration for each target. Diluting the mix of plasmidic DNA in a background of plant DNA set at $1 \mathrm{ng}$ $\mu l^{-1}$ did not significantly modify the efficiency and sensitivity of the PCR, except for $M$. fructicola and $M$. laxa at the lowest target concentrations (438 and 4,740 pc/tube, respectively; Fig. 1). When spiking host plant DNA with genomic target DNA, repeatable positive signals (3 of 3 ) were obtained down to $0.5 \mathrm{pg}$ for $M$. fructicola, $M$. laxa, and $M$. fructigena, with a mean $\mathrm{Ct}$ value of 34.97, 34.82, and 32.49, respectively (data not shown).

The results of detection in artificially inoculated apple and peach from sets $\mathrm{A}, \mathrm{B}$, and $\mathrm{C}$ are shown in Table 4. Infected skin fruit DNA from set A (single-species inoculation) or set B (equal mixture of two species) yielded positive results in quadruplex real-time PCR with the respective primer-probe combination, regardless of the fruit type. The quadruplex test was also able to generate positive results with DNA extracts obtained from unequal mixtures of fruit skin infected by the three species (set $\mathrm{C}$ ), regardless of the species mixture ratio, except for one of five replicates with the lowest quantity of M. laxa (Table 4). DNA extracts from the negative control peach and apple fruit from sets $\mathrm{A}, \mathrm{B}$, and $\mathrm{C}$ yielded no $\mathrm{Ct}$ value for any of the three targets.

Implementation of a DNA extraction quality control. DNA extracts were obtained from six varieties of apple (Ariane, Altesse, Golden, Royal Gala, Pirouette, and Boskoop) and tested by the quadruplex assay. The $18 \mathrm{~S}$ Uni Ct values yielded with these DNA templates followed a normal distribution $(w=0.9769, P$ value $=0.07866)$, and the $\mathrm{Ct}_{18 \mathrm{~s}}$ value could be calculated $(=14.6)$ according to the mean $(=12.8)$ and $\mathrm{SD}(=0.9)$. Therefore, this $\mathrm{Ct}_{18 \mathrm{~S}}$ was retained as the cutoff value for routine analysis. On the one hand, the DNA templates which yielded negative results for all three target species were considered as true negative, providing that the corresponding mean $18 \mathrm{~S}$ Uni $\mathrm{Ct}$ value was below 14.6, meaning that these DNA templates were of sufficient quality, with no significant inhibition effect. On the other hand, the negative results obtained for a DNA template with a mean $18 \mathrm{~S}$ Uni $\mathrm{Ct}$ value above $\mathrm{Ct}_{18 \mathrm{~S}}$ should be regarded as questionable because the quality of the DNA extraction would be doubtful (degraded DNA, inhibition, and so on). In this case, dilution to the 10th or to the 100th was done before retesting.

Replicability, reproducibility, and transfer to different thermal cyclers. Using target plasmidic DNA, high levels of replicability and reproducibility were reached for the quadruplex real-time PCR assay. The intraassay $\mathrm{CV}$ ranged from 0.49 to $1.50,2.76$ to 5.08 , and 0.78 to $1.32 \%$, for M. fructicola, M. laxa, and M. fructigena, respectively, whereas the interassay $\mathrm{CV}$ ranged from 0.91 to $1.94,5.02$ to 6.32 , and 1.40 to $1.68 \%$ for M. fructicola, M. laxa, and M. fructigena, respectively (Table 5). 
Using plasmidic DNA target set at LOD and $100 \times$ LOD concentrations, significantly higher $\mathrm{Ct}$ values $(P<0.05)$ were obtained using the LC480 thermal cycler, with difference of $\mathrm{Ct}$ values ranging from 0.46 to 4.17 (Fig. 2), but the qualitative results (positive or negative) remained as expected. The specificity of each test was not affected, because no cross reaction was observed with DNA from nontarget species, regardless of the equipment used.

Robustness of the quadruplex assay. The robustness of the molecular tool was assessed with cocktails of target DNA with concentrations close to the LOD (Fig. 3).

For each of the three targets, the results of the quadruplex real-time PCR test were significantly affected by a deliberate $\pm 10 \%$ variation of the reaction volume. However, by varying the reaction volume, the largest difference between mean $\mathrm{Ct}$ values was still inferior to 0.79 , meaning that there was no consequence from a qualitative perspective.

With very few exceptions (almost all samples had a Ct value variation not exceeding 0.30), increasing or decreasing the volume of DNA template by $10 \%$ did not significantly affect the mean $\mathrm{Ct}$ value, regardless of the target species and concentration.

In contrast, a $2^{\circ} \mathrm{C}$ variation of the hybridization and polymerization temperature frequently resulted in a significant effect on the mean $\mathrm{Ct}$ value for the three target species. However, the mean $\mathrm{Ct}$ variation never exceeded 2.23, 0.96, and 0.71 , for $M$. fructicola, $M$. laxa, and $M$. fructigena, respectively, which meant that each pathogen would be still detected, even at the lowest concentration levels.

Finally, during the robustness experiments, M. polystroma total DNA (strain CBS 102686), set at $1 \mathrm{ng} \mu l^{-1}$, was also tested by quadruplex real-time PCR. M. polystroma DNA never yielded positive results $(\mathrm{Ct}>40)$ in any of the tests, and no cross reactions were observed between any of the three Monilinia primer-probe combinations and DNA from the two other Monilinia spp., even in the least stringent conditions (i.e., $-10 \%$ reduction of reaction volume, + $10 \%$ increase of template DNA volume, or $-2^{\circ} \mathrm{C}$ decrease of hybridization temperature; data not shown).

\section{Discussion}

Brown rot is an economically devastating disease in fruit crop production worldwide. $M$. fructicola, $M$. laxa, and $M$. fructigena are the most prevalent fungi responsible for this disease. Depending on the national regulations, only one or two of these species are listed as quarantine pests, although the others may be present. Therefore, it is important to have reliable means to quickly identify the quarantine species in order to prevent their entry or to make sure of the taxa involved during field or nursery surveys for implementing efficient chemical control strategies. Real-time is a sensitive, specific, and robust tool for phytosanitary control that is recommended in many

Table 5. Intra- and interassay coefficients of variations $(\mathrm{CV})$ based on the mean cycle threshold $(\mathrm{Ct})$ values for the multiplex assay ${ }^{\mathrm{a}}$

\begin{tabular}{|c|c|c|c|c|c|c|}
\hline \multirow[b]{2}{*}{ Target $^{\mathbf{b}}$} & \multicolumn{2}{|c|}{ Monilinia fructicola } & \multicolumn{2}{|c|}{ M. laxa } & \multicolumn{2}{|c|}{ M. fructigena } \\
\hline & $\mathrm{Ct} \pm \mathrm{SD}$ & $\operatorname{CV}(\%)$ & $\mathrm{Ct} \pm \mathrm{SD}$ & $\mathrm{CV}(\%)$ & $\mathrm{Ct} \pm \mathrm{SD}$ & $\mathrm{CV}(\%)$ \\
\hline \multicolumn{7}{|l|}{ Replicability } \\
\hline $1,000 \times \mathrm{LOD}$ & $20.80 \pm 0.31$ & 1.50 & $20.70 \pm 0.78$ & 3.78 & $19.85 \pm 0.26$ & 1.32 \\
\hline $100 \times$ LOD & $24.13 \pm 0.12$ & 0.49 & $25.85 \pm 0.71$ & 5.08 & $23.19 \pm 0.18$ & 0.78 \\
\hline $10 \times$ LOD & $28.55 \pm 0.31$ & 1.08 & $>40$ & nd & $27.72 \pm 0.24$ & 0.85 \\
\hline Mom $1^{\mathrm{c}}$ & $>40$ & nd & $19.93 \pm 0.81$ & 4.05 & $>40$ & nd \\
\hline \multicolumn{7}{|l|}{ Reproducibility } \\
\hline $1,000 \times$ LOD & $20.62 \pm 0.19$ & 0.91 & $22.35 \pm 1.41$ & 6.32 & $20.17 \pm 0.34$ & 1.68 \\
\hline 100× LOD & $24.22 \pm 0.27$ & 1.12 & $27.76 \pm 1.62$ & 5.82 & $23.73 \pm 0.37$ & 1.56 \\
\hline $10 \times$ LOD & $28.80 \pm 0.56$ & 1.94 & $>40$ & nd & $27.94 \pm 0.39$ & 1.40 \\
\hline
\end{tabular}

a Values are the mean $\mathrm{Ct}$ value \pm standard deviation $(\mathrm{SD} ; n=10) ;>40$ indicates not detected and $\mathrm{nd}=$ not determined.

b Target concentration: plasmidic DNA diluted in fruit DNA at $1 \mathrm{ng} / \mu 1$. Limits of detection (LOD) correspond to 438, 474, and 480 plasmidic copies of target per polymerase chain reaction tube for M. fructicola, M. laxa, and M. fructigena, respectively.

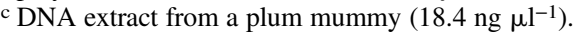

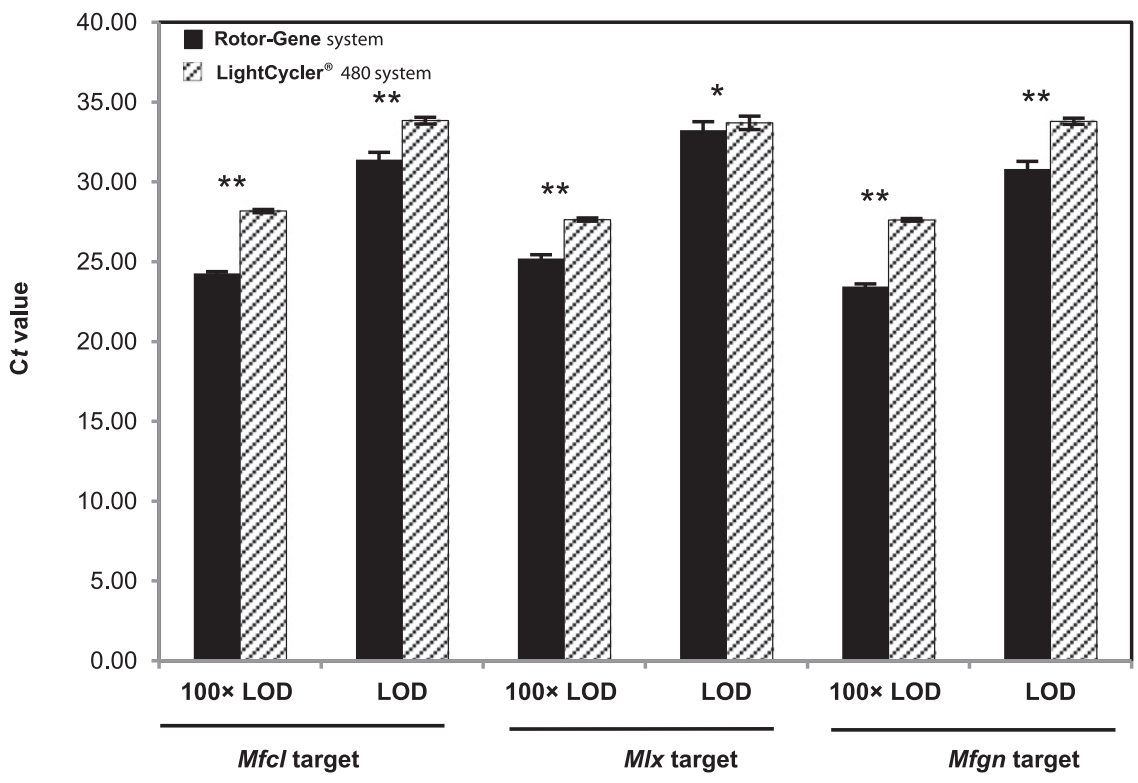

Fig. 2. Comparative study of the assay using the Rotor-Gene system (black block) or the LightCycler 480 system (hatched blocks) by testing limit of detection (LOD) and 100 $\times$ LOD concentrations for the three targets (Monilinia fructicola, M. laxa, and M. fructigena). Values are the mean cycle threshold (Ct) values \pm standard deviation ( $n=10) ;{ }^{*}$ and ${ }^{* *}$ indicate $P$ value $<0.05$ and 0.001 , respectively. No amplification of nontarget species DNA was obtained. 
international diagnostic protocols (EPPO 2009b, 2014). An additional interesting feature of real-time PCR using hydrolysis probes is that several targets may be detected simultaneously in the same reaction, thus limiting costs and reducing the turnaround time for analysis. Multiplexing is particularly useful in cases where several different targets may be present at the same time in the same ecological niche, as may be the case for Monilinia spp. on fruit. In this work, we report the development of a new real-time PCR quadruplex assay that enables the simultaneous detection of $M$. fructicola, M. laxa, and $M$. fructigena in diseased plant tissue. For each species, the test amplified a specific region of the MO368 SCAR marker described by Côté et al. (2004). This marker is located in a gene whose function is still unknown; however, it was proven to be a good candidate to distinguish $M$. fructicola, M. laxa, $M$. fructigena, and M. polystroma (Côté et al. 2004; Riccioni and Valente 2015). Côté et al. (2004) selected this marker following a random amplified polymorphic DNA approach, and developed a detection tool combining the use of species-specific reverse primers and the observation of polymorphic sizes between the amplicons yielded with DNA from each of the four species. With the new test developed during this work, the three major species responsible for brown rot (i.e., M. fructicola, M. laxa, and $M$. fructigena) are distinguishable in one step by the real-time PCR assay. In addition, the 18S Uni assay (Ioos et al. 2009) was used systematically in association with the species-specific primer-probe combinations to check the quality of each DNA template and to prevent false-negative results potentially caused by the presence of PCR inhibitors or DNA shearing. Unfortunately, no specific primer-probe combination could be developed for $M$. polystroma. As already shown by Petróczy et al. (2012), there was only a very low level of polymorphism between $M$. fructigena and $M$. polystroma in the region of the genome corresponding to the MO368 SCAR marker, and this region was not suitable to design acceptable $M$. polystromaspecific oligonucleotides.

DNA extracts from a large representative set of $M$. fructicola, $M$. laxa, and $M$. fructigena strains tested in this study yielded the expected positive results with the quadruplex real-time assay. The isolates were collected from many different stone and pome fruit orchards with various geographical origins and over many years, which
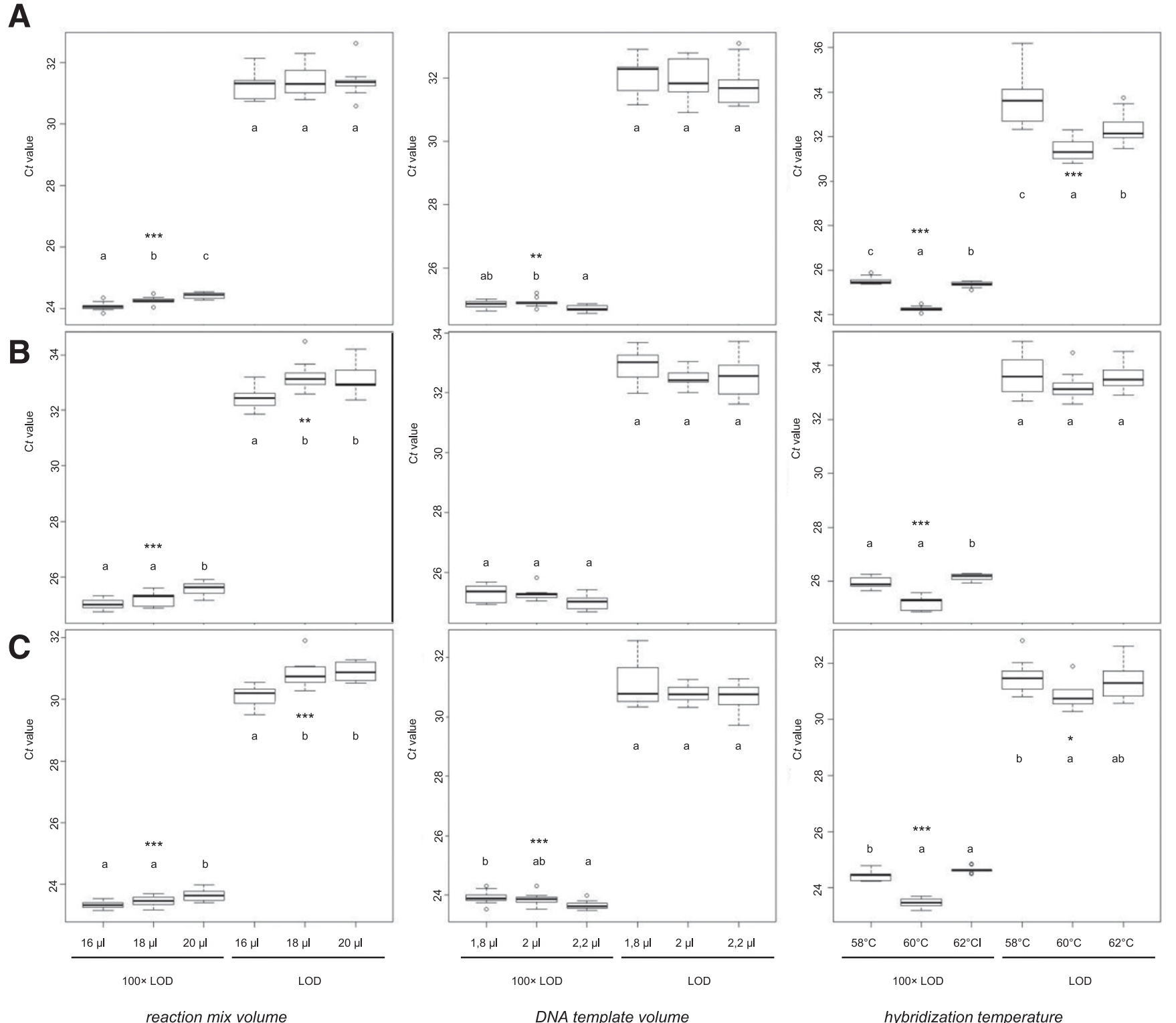

Fig. 3. Robustness of the multiplex assay assessed with varying volume of reaction (left), volume of DNA template (center), and hybridization temperature (right) for A, Monilinia fructicola; B, M. laxa; and C, M. fructigena plasmidic DNA controls diluted in 1× Tris-EDTA buffer, set at limit of detection (LOD) and 100x LOD concentrations. LOD concentrations correspond to 438,474 , and 480 plasmidic copies of target per polymerase chain reaction tube for $M$. fructicola, $M$. laxa, and $M$. fructigena, respectively. The value are the mean cycle threshold $(\mathrm{Ct})$ value \pm standard deviation, $n=10 ;{ }^{*}$, ${ }^{* *}$, and ${ }^{* * *}$ indicate $P$ value $<0.05,0.01$, and 0.001 , respectively. Mean Ct values with the same letters are not different according to Tukey's honestly significant difference. 
supports the inclusivity of the test. None of the five $M$. polystroma isolates yielded any $\mathrm{Ct}$ value with $M$. fructicola, M. fructigena, or M. laxa primer-probe combinations, thus confirming the analytical specificity of the test. Moreover, no Ct value was obtained with genomic DNA from species closely related to the genus Monilinia or frequently associated with brown rot disease or commonly found on decaying fruit or infected stems (i.e., secondary invaders or saprophytic fungi). In addition to the four major species of Monilinia spp. affecting fruit, two others species (namely, M. mumecola and M. yunnanensis) have recently been described in China and Japan by Hu et al. (2011) on peach. Unfortunately, despite several attempts, we could not have access to any representative strains of these taxa in the course of our experiments, and the specificity of our test could not be further assessed. In addition to in vitro testing that must be carried out to confirm the specificity of the real-time PCR assays, it may be recommended to assess the specificity of each primer-probe combination by BLAST analysis on DNA databases such as GenBank. This has to be done during the initial validation steps but also on a regular basis in order to continuously monitor the specificity of the tests with updated databases. However, in this study, the genomic region which is targeted by this multiplex assay is a SCAR marker, whose function is unknown (Côté et al. 2004). In this respect, and unlike housekeeping genes or genes commonly used for barcoding, the number of orthologous sequences for this MO368 marker is not expected to increase in DNA databases. Therefore, in our case, blasting the primer-probe combinations on a regular basis does not seem to be an efficient way to monitor the specificity of the assay over time, and in vitro testing for any new, closely related taxon will remain the only option.

With respect to $M$. fructicola, the sensitivity of the assay developed in this study appeared to be slightly improved compared with the conventional PCR test initially developed by Côté et al. (2004) and was similar to the level achieved by Ioos and Frey (2000), with a positive signal yielded by a DNA concentration down to 25 and 0.5 pg, respectively (Riccioni and Valente 2015). This result is not surprising because the assay developed by Ioos and Frey (2000) targets the ITS rDNA region, which is a multicopy marker. Copies of the MO368 marker described by Côté et al. (2004) are probably less frequent in the Monilinia genome but the use of a fluorescent probe helps to detect lower amounts of target DNA.

The performances of the test were also assessed during this work using a plasmidic DNA target. The quadruplex real-time PCR assay was shown to be highly replicable and reproducible because intraand interassay $\mathrm{CV}$ were very low. The slightly worse values obtained for the M. laxa test may be explained by the fact that this primerprobe combination is more sensitive to plant DNA inhibition effect during PCR, as suggested by the sensitivity experiments. However, this effect was only observed for target concentrations close to the LOD. In addition, we assessed the ability of the test to stand slight variations of the reaction or DNA template volumes and hybridization temperature. The results demonstrated that the quadruplex assay remained sensitive and specific, despite less stringent reaction conditions, and suggested that the test might be able to stand limited experimental errors or equipment drift (e.g., pipetting errors or thermic issues with the thermal cycler) without compromising the reliability of the results. In addition, changing the PCR equipment did not affect the sensitivity or the specificity of the results, meaning that the assay could be easily transferred to different kinds of PCR platforms (block or rotor systems).

The test that was developed in this study is a multiplex assay that is able to detect any of the three major Monilinia spp. occurring on pome and stone fruit individually. However, one of the advantages of the multiplex format is that the simultaneous presence of more than one species can also be detected. The presence of two Monilinia spp. on the same fruit are not uncommon in stone and pome orchards (Ondejková et al. 2010; Patocchi et al. 2009) and was observed during our study on fresh fruit and mummy fruit. Our experimental results with artificially inoculated fruit demonstrated that two and even all three species could still be detected when present in the same fruit sample, except when very low M. laxa DNA amounts were mixed with larger amounts of $M$. fructigena and M. fructicola DNA. However, as far as we know, natural tri-infections have not been reported thus far in orchards.

This new assay should also be useful for monitoring single or multiple infections by $M$. fructicola, $M$. fructigena, or M. laxa in orchards, so that any chemical treatment could be adapted in favor of an efficient disease management strategy. Indeed, a wise use of fungicides should put a brake on the development of resistant strains and comply with the enforced regulatory policies regarding human safety.

\section{Acknowledgments}

This research was funded by ANSES. We thank G. Van Leeuwen for supplying JAP2317 M. polystroma isolate; A. Micoud and F. Rémuson for providing $M$. laxa and M. fructigena strains; and J.-C. Rinaldi, L. Brun, V. Mercier, H. Chenevetot, C Gros, P. Lamanda, and N. Schenck for supplying naturally infected samples.

\section{Literature Cited}

Batra, L. R. 1991. World Species of Monilinia (Fungi): Their Ecology, Biosystematics and Control. Mycologia Memoir, No. 16. J. Cramer, Berlin, New York.

Boehm, E. W. A., Ma, Z., and Michailides, T. J. 2001. Species-specific detection of Monilinia fructicola from California stone fruits and flowers. Phytopathology 91:428-439.

Bustin, S. A., Beaulieu, J.-F., Huggett, J., Jaggi, R., Kibenge, F. S. B., Olsvik, P. A., Penning, L. C., and Toegel, S. 2010. MIQE précis: Practical implementation of minimum standard guidelines for fluorescence-based quantitative real-time PCR experiments. BMC Mol. Biol. 11:74.

Chen, F., Liu, X., and Schnabel, G. 2013. Field strains of Monilinia fructicola resistant to both MBC and DMI fungicides isolated from stone fruit orchards in the Eastern United States. Plant Dis. 97:1063-1068.

Côté, M.-J., Tardif, M.-C., and Meldrum, A. J. 2004. Identification of Monilinia fructigena, M. fructicola, M. laxa, and Monilia polystroma on inoculated and naturally infected fruit using multiplex PCR. Plant Dis. 88:1219-1225.

Edgar, R. C. 2004. MUSCLE: Multiple sequence alignment with high accuracy and high throughput. Nucleic Acids Res. 32:1792-1797.

EPPO. 2009a. PM 7/18(2): Monilinia fructicola. Bull. OEPP/EPPO Bull. 39: 337-343.

EPPO. 2009b. PM 7/91(1): Gibberella circinata. Bull. OEPP/EPPO Bull. 39: 298-309.

EPPO. 2010. PM 7/98 (1): Specific requirements for laboratories preparing accreditation for a plant pest diagnostic activity. Bull. OEPP/EPPO Bull. 40:5-22.

EPPO. 2014. PM 7/85 (2) Plasmopara halstedii. Bull. OEPP/EPPO Bull. 44 350-359.

EPPO Reporting Service. 2011. First reports of Monilia polystroma in Hungary and the Czech Republic. No. 6:2011/2134

Förster, H., and Adaskaveg, J. E. 2000. Early brown rot infections in sweet cherry fruit are detected by Monilinia-specific DNA primers. Phytopathology 90: 171-178.

Fox, J. 2005. The R Commander: A basic statistics graphical user interface to R. J. Stat. Softw. 14:1-42.

Fulton, C. E., and Brown, A. E. 1997. Use of SSU rDNA group-I intron to distinguish Monilinia fructicola from M. laxa and M. fructigena. FEMS Microbiol. Lett. 157:307-312.

Gell, I., Cubero, J., and Melgarejo, P. 2007. Two different PCR approaches for universal diagnosis of brown rot and identification of Monilinia spp. in stone fruit trees. J. Appl. Microbiol. 103:2629-2637.

Hilber-Bodmer, M., Knorst, V., Smits, T. H. M., and Patocchi, A. 2012. First report of Asian brown rot caused by Monilia polystroma on apricot in Switzerland Plant Dis. 96:146.

Hrustic, J., Mihajlovic, M., Grahovac, M., Delibasic, G., Bulajic, A., Krstic, B. and Brankica, T. 2012. Genus Monilinia on pome and stone fruit species. Pestic. Fitomed. 27:283-297.

Hu, M.-J., Cox, K. D., Schnabel, G., and Luo, C.-X. 2011. Monilinia species causing brown rot of peach in China. PLoS One 6:e24990.

Hughes, K. J. D., Fulton, C. E., McReynolds, D., and Lane, C. R. 2000 Development of new PCR primers for identification of Monilinia species. Bull. OEPP/EPPO Bull. 30:507-511.

Ioos, R., Fourrier, C., Iancu, G., and Gordon, T. R. 2009. Sensitive detection of Fusarium circinatum in pine seed by combining an enrichment procedure with a real-time polymerase chain reaction using dual-labeled probe chemistry. Phytopathology 99:582-590.

Ioos, R., and Frey, P. 2000. Genomic Variation within Monilinia laxa, M fructigena and M. fructicola, and application to species identification by PCR Eur. J. Plant Pathol. 106:373-378.

Luo, Y., Ma, Z., Reyes, H. C., Morgan, D., and Michailides, T. J. 2007. Quantification of airborne spores of Monilinia fructicola in stone fruit orchards of California using real-time PCR. Eur. J. Plant Pathol. 118:145-154.

Ma, Z., Luo, Y., and Michailides, T. J. 2003. Nested PCR assays for detection of Monilinia fructicola in stone fruit orchards and Botryosphaeria dothidea from pistachios in California. J. Phytopathol. 151:312-322. 
Martini, C., Lantos, A., Di Francesco, A., Guidareli, M., D'Aquino, S., and Baraldi, E. 2014. First report of Asiatic brown rot caused by Monilinia polystroma on peach in Italy. Plant Dis. 98:1585.

Muñoz, Z., Moret, A., and Bech, J. 2008. Caracterización morfológica y molecular de aislados de Monilinia spp. y pruebas de patogenicidad sobre manzana. Agrociencia 42:119-128.

Ondejková, N., Hudecová, M., and Bacigálová, K. 2010. First report on Monilinia fructicola in the Slovak Republic. Plant Prot. Sci. 46:181-184.

Patocchi, A., Bunter, A., Gerber, A., and Hilber-Bodmer, M. 2009. Première apparition de Monilinia fructicola dans un verger de fruits à noyau en Suisse. Rev. Suisse Vitic. Arboric. Hortic. 41:113-116.

Petróczy, M., and Palkovics, L. 2009. First report of Monilia polystroma on apple in Hungary. Eur. J. Plant Pathol. 125:343-347.

Petróczy, M., Szigethy, A., and Palkovics, L. 2012. Monilinia species in Hungary: Morphology, culture characteristics, and molecular analysis. Trees (Berl.) 26: 153-164.

Poniatowska, A., Michalecka, M., and Bielenin, A. 2013. Characteristic of Monilinia spp. fungi causing brown rot of pome and stone fruits in Poland. Eur. J. Plant Pathol. 135:855-865.
R Core Team. 2015. R: A Language and Environment for Statistical Computing. R Foundation for Statistical Computing, Vienna.

Riccioni, L., and Valente, M. T. 2015. Comparison of different PCR tests to identify Monilinia fructicola. Bull. OEPP/EPPO Bull. 45:33-40.

Sonoda, R. M., Ogawa, J. M., and Manji, B. T. 1982. Use of interactions of cultures to distinguish Monilinia laxa from M. fructicola. Plant Dis. 66:325-326.

Van Brouwershaven, I. R., Bruil, M. L., Van Leeuwen, G. C. M., and Kox, L. F. F. 2010. A real-time (TaqMan) PCR assay to differentiate Monilinia fructicola from other brown rot fungi of fruit crops. Plant Pathol. 59:548-555.

Van Leeuwen, G. C. M., Baayen, R. P., Holb, I. J., and Jeger, M. J. 2002. Distinction of the Asiatic brown rot fungus Monilia polystroma sp. nov. from M. fructigena. Mycol. Res. 106:444-451.

Vasić, M., Duduk, N., and Ivanović, M. S. 2013. First report of brown rot caused by Monilia polystroma on apple in Serbia. Plant Dis. 97:145.

White, T. J., Bruns, T., Lee, S., and Taylor, J. 1990. Amplification and direct sequencing of fungal ribosomal RNA genes for phylogenetics. Pages 315-322 in: PCR Protocols: A Guide to Methods and Applications. M. A Innis, D. H. Gelfand, J. J. Sninsky, and T. J. White, eds. Academic Press, New York. 